\title{
BASKETBALL IN THE TERRITORY OF FORMER YUGOSLAVIA IN 1941
}

\author{
Simović Slobodan ${ }^{1}$, Pavlović Petar ${ }^{1}$, Pantelić Kristina ${ }^{1}$ \& Grgić Zrinko ${ }^{2}$ \\ ${ }^{1}$ Faculty of Physical Education and Sports, Banja Luka, Bosnia and Herzegovina \\ ${ }^{2}$ Croatia Sports Museum, Zagreb, Croatia
}

\begin{tabular}{lr} 
DOI: $10.5550 /$ sgia.1002011 $\quad$ COBISS.BH-ID 1846552 & $\begin{array}{r}\text { SCINETIFIC WORK REVIEW } \\
\text { UDC: } 796.323 .2(497.1) " 1941 "\end{array}$ \\
\hline
\end{tabular}

\section{SUMMARY}

Development of basketball in the territory we are talking about, during the WW II, remained quite un-researched, so the subject and the goal of this paper is to research, analyze, highlight and obtain from oblivion that same period. We hope to stir up the sports historians, and also other readers interested in history of sports for further research.

During writing usual historical method was used (finding of primary historical sources, their critics, as also the finding and studying of the secondary historical sources). A numerous sources made in that time were reviewed and consulted (magazines, newspapers, papers, records, reports, overwrites, etc.) in: archives, libraries, institutes, private archives and museums of sports of former Yugoslavia, as also the sources made afterword.

During 1941 basketball took place in Belgrade, Novi Sad, Split, Šibenik, Dubrovnik and Kotor. The competitions were played occasionally but most intensively in Belgrade. Serbian Basketball Federation was founded in September, also in Belgrade.

Key words: basketball, competitions, II War World.

\section{INTRODUCTION}

In the territory of former Yugoslavia basketball starts to play first among Sokol youth, and then in Sokol societies. In elementary school Studenci, near Maribor, it starts in 1919th. It was introduced by Ciril Hočevar, the teacher of that school, who met basketball even before 1914 by working in schools in Maribor, where basketball was played among school youth.

In Belgrade it starts in the beginning of October 1923 after the visit of Mister William A. Wailland, deputy of the Red Cross. He came to Belgrade because of the organization of children's games and playgrounds. Course about children games, for male and female teachers of primary schools, teachers of gymnastics, Sokol and Scout leaders, was held from 27 September to 18 October of that year, at the playgrounds of elementary school $\mathrm{Sa}$ vamala and the Cathedral Church. Among other games, the course participants were shown the new American game - basketball. Upon completion of the course, male students of Second Belgrade High School started to play it. After Belgrade, with the same goal Wailland went to: Sarajevo, Novi Sad, Bitola, Skopje, Nis, Zagreb, Split, and Ljubljana, where he also presented a new game. Soon basketball begins to play in those, and other places: Bitola 1924, Novi Sad, 1924, Niš 1925 , Mostar, 1926, Tuzla, 1927, Zadar 1928, Zagreb 1929, Štip 1932, Karlovac 1933, Boka Kotorska 1935, Sušak 1938, Split 1939, Petrovgrad 1939, Sarajevo 1939, Ljubljana 1939, Dubrovnik 1940, and so on.

Period from 1929 to 1940 is extremely important for the development of basketball in the region of the former Yugoslavia. Basket- 
ball begins to play, not only among Sokol and school youth, but also among students. Many matches were played among existing teams. They begin to play the first international club and representative games.

Student representation of the Kingdom of Yugoslavia played its first international game with the representation of Italy B, on March $20^{\text {th }} 1938$ in Rome. On the $5^{\text {th }}$ of July of the same year, on the 10th Allsokol reunion in Praga, they played international game with representation of the Czechoslovakia.

Sokol union of the Kingdom of Yugoslavia (SSKJ), as a representative of Yugoslavia was accepted to International Basketball Federation (FIBA) in middle of December 1936.

First championship of SSKJ in basketball was held on 28 and 29 September 1940 in Borovo, were participated 180 basketball players, male and female, divided in 15 teams from seven Sokol districts.

We could think that in the time of Second World War people did not pay much attention to sports activities. But, that was not really the case. Research showed that people in those hard times did pay attention, among other things, to various sport activities, and also to basketball. Even do it was greatly played already, a long time people were silent and wrote very little about it.

Development of basketball in the territory we are talking about, during the WW II, remained quite un-researched, so the subject and the goal of this paper is to research, analyze, highlight and obtain from oblivion that same period. We hope to stir up the sports historians, and also other readers interested in history of sports for further research.

\section{METHOD}

During writing usual historical method was used (finding of primary historical sources, their critics, as also the finding and studying of the secondary historical sources). A numerous sources made in that time were reviewed and consulted (magazines, newspapers, papers, records, reports, overwrites, etc.) in: archives, libraries, institutes, private archives and museums of sports of former Yugoslavia, as also the sources made afterword.

\section{RESULTS AND DISCUSION}

\section{Basketball activities from January until the $6^{\text {th }}$ of April 1941}

In organization of Headquarters of SSKJ from 2 to 6 January 1941 in Sokol house of Sokol society Beograd-Matica, in Delgradska Street no. 27 was held federal course for basketball. The host of the course was Marjan Maržan, and all accepted candidates had to apply on January $2^{\text {nd }}$ until $14.30 \mathrm{~h}$. The ones being late will not be accepted, better said will not be able to attend the course.

All said about the course is clearly said in the Annunciation - the letter of the Headquarters of the SSKJ no. 12943/40, addressed to sister Sofija Mladenović, member of Sokol society Beograd-Matica.

"With this we inform you that you have been accepted to the federal course for BASKETBALL witch will be held from 2 to 6 January 1941 in the Home of Sokol society Beograd-Matica (Deligradska 27). On the 2 January 1941 you have to report yourself to the host of the course, brother Marjan Maržan until 14.30h. You will get the course agenda after you apply. Those being late and un-regular will not be accepted, better said will be removed from the course." (see the picture of the letter)

In the cause of basketball popularization, in the magazine "Yugoslav sport and Air forces", no. 2, from 7 January 1941, published in Belgrade, in page 38 , Maržan published the article entitled "Basketball match in Belgrade" in which he described the game played in Belgrade in the late 1940 among teams of School for physical education (ŠTV) from Belgrade, and Sokol society Beograd-Matica. He played in the Beograd-Matica Sokol society, and scored six points.

In Belgrade on 19 January 1941, in the hall of Sokol house Soko Beograd I, were played three games. Six teams competed: three from Sokol society Beograd-Matica (members, generations of boys and girls), two teams of students (man and woman of ŠTV from Belgrade) and the team of Sokol society Soko I from Belgrade.

In his diary, Miodrag Stefanović writes: 
"Last week were held three basketball games in Belgrade, in Sokohall Beograd I. Three generations of Soko society BeogradMatica attended in matches with students $(\mathrm{M}, \mathrm{W})$ of ŠTV, and also the generations of Soko I.“" (Maržan, 1941, 6)

PICTURE 1

Invitation letter to Sofia Pekic to attend the national basketball course in 1940

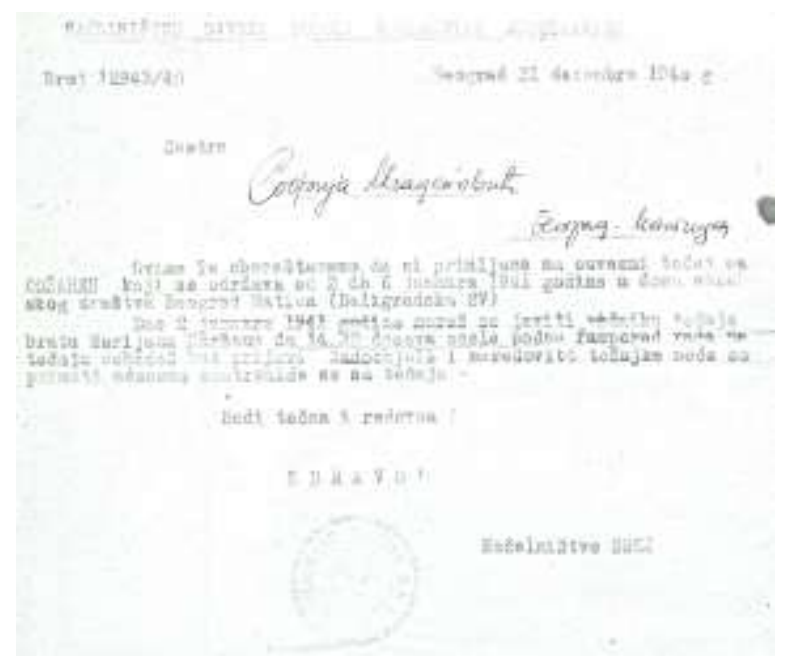

First game was played between the generation of SS Beograd-Matica and the students of ŠTV. Students won with the result 7-6 (66). For Matica team played: Ružica Radovanović (scored all 6 points), Draga Đurović, Kosara Petraček, Mira Pavliček and Sofija Mladenović, and for students: Vacac, Rižnar, Matejić, Poljaković, Jevtić, Lešnik and Ferster. For students scored: Vacac (3) and Poljaković (4). The referee was Miodrag Stefanović.

„Before the beginning of the game the chief of the Soko I, brother Selimir Radovanović saluted the guests pointing the hard work of SS Beograd-Matica and his coordinator for games because of the progress of basketball in Belgrade. In the second half-time, after tight fight, in which the dominant was the play of sister Ružica Radanović, the game ended with 7-6. Students won, but this time un-deserved, because the generation of Matica was, if not even better, than a fair opponent." (Ibid)

Second game was played by the members of Matica and students of ŠTV, with presence of huge number of spectators. The game end- ed with the winning of Matica 23-22. The referee was Selimir Radovanović. For Matica played: Maržan, Travica, Debelja, Tričković, Nikolić, Stojković, Mišeljić and Stefanović, and for students: Šuput, Lašman, Kokot, Cizej, Tominić, Vlahović, Dančević and Kobali. For Matica scored: Maržan (3), Debelja (2), Stojković (10), Mišeljić (4) and Stefanović (4), and for students: Šuput (2), Lašman (4), Kokot (4), Tominić (2), Vlahović (4) and Kobali (6). With Maržan, among other, stands:

"...but now starts the tough game forced by students. The game ends with the deserved minimum win of Matica scored by Maržan from free-through 23-22. The game was refereed very good by the brother Selimir Radovanović. Only, he let the very hard play, which can have much worse consequences on a slippery ground." (Ibid) Miodrag Stefanović wrote about that game in his diary on Sunday $19^{\text {th }}$ January 1941:

"Than comes our member from ŠTV. Our first five Travica, Nikolić, Vasa, Mišeljić, myself, started peaceful and calm game. Vasa leaves the game, and Maja enters. Butcher game of ŠTV continues. Than Maja was fouled so hard that Sele had to assign penal. Penal has to determine who is going to win... and finally goal... and end... We won. Than I saw that generation players were no gentleman because they were saying that their team is not complete, even thou it was. Even Kobali and Ratko played together. Result was 23 to 22 for us" (according to Paunić, 1981, 298)

In the third, last game, meet generation of Matica with the team of Soko I. Soko deserved to win with the result 14-8 (12-6). The referee was Marjan Maržan, who refereed "very strict and did not let the game to gain the unpermitted hardness" (Maržan, 1941, 6)

For Matica played: Oljača, Enci, Petković, Tomić, Mladenović, Vujičić, Senić, Denić, Ostojić and Aksentijević, and for the Soko I: Nenadović, Mikulić, Lermer, Jotić, Popović, Tomin and Milošević. For Matica scored: Enci (2), Petković (1) and Denić (5), and for the Sokols: Nenadović (10), Mikulić (2) and Milošević (2).

These games, the same as the ones before them, were used for further popularization of 
basketball in Belgrade.

Maržan writes:

"We can be proud that Sokols propagate that game, and go far ahead from all the rests who think that they are more forward than us. The work of the SS BeogradMatica should be especially commended because they managed to play with three groups, and with very good resultas." (Ibid) It was planned that on Sunday, 26 of January of the same year play three games between: SS Petrovgrad and SS Beograd-Matica, SS Zemun-Matica and SS Beograd I, and between generation of Beograd-Matica and SAŠKK.

„The game will start on the $26^{\text {th }}$ this month; in the morning, at 11 o'clock, and the price of the entrance is minimal, because the games have the propaganda character." (Ibid)

Maržan predicts that the games will be nice and interesting for the spectators, and most of all because of the presence of the basketball players from Petrovgrad, whom he considers as great players.

„As the brothers from Petrovgrad are very good players, and they have participated at the federal games of basketball in Belgrade, the meeting will be satisfyingly interesting and beautiful, and the rest of the program also promises nice games." (Ibid)

It is unknown to us if the planed games were held.

According to diary of Miodrag Stefanović the last game in period between two wars (1918-1941), and right before the very attack of Hitler on Yugoslavia, was played in Belgrade on Sunday $16^{\text {th }}$ March 1941 between the teams of SS Zagreb II and SS Matica-Beograd. Zagreb team won with the result 59-32 (2914).

In the diary, Sunday, 16 March 1941, Stefanović writes:

“...we lost with 59-32 (29-14) even thou we were fully equal. I achieved only six goals, because Zlatko was watching me so good... that I could not move at all." (according to Paunić, 2007, 166)

After staying of Marjan Maržan in Belgrade where he was mostly working on spreading of basketball, on 3 February 1941 he leaves Belgrade, from December of 1939, and goes to
Ivanec. Gala sendoff was made in his honor by his friends - basketball players and all his admirers. Stefanović in his diary from Monday, 3 February 1941 writes about how they have escorted Maja in the railway station:

PICTURE 2

Marjan Maržan

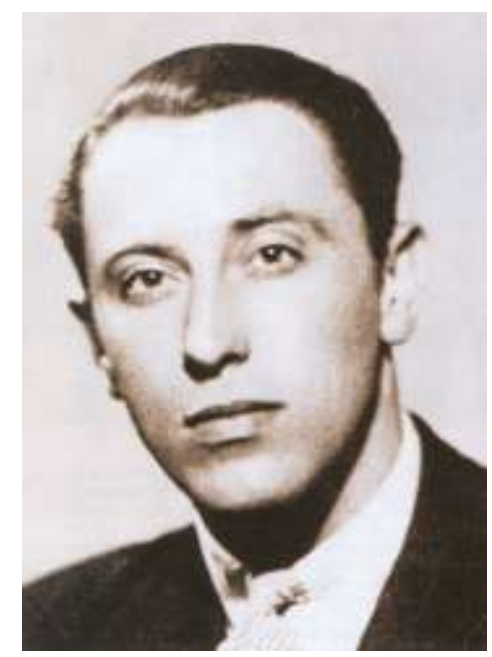

"The last day that Maja is with us... and in the afternoon when I went to the station a whole group of friends was already there, with Maja in the middle. He was very excited. He's getting all sorts of gifts. The moment of our separation is closing, and I have noticed from all present faces that they were excited. One man from our neighborhood we all loved and will always remember. Maja enters the train... than we could hear from everyone goodbye - goodbye - goodbye and the train quickly left the station." (according to Paunić, 1981, 298)

Right with the arrival to Ivanec, which is somewhere around Varaždin on 18 February 1941, he addresses the letter to Miodrag Stefanović in Belgrade, in which, among other things, writes:

"That is my biggest whish, and it would be a great joy to me that during my arrival to Belgrade to academy of Soko II from Zagreb I see that everything is in order... and don't let them disappear from basketball people. You should all work on that, to gather as many of you as you can, to get new members and also not lose the old ones, and that will be a real success. I 
would like to see gathered old basketball society renewed with some new "stars"." (according to Paunić, 1981, 318)

In the rest of the letter he writes:

"Wish Paja success in his work. But now he does not have to trouble so much, because that main thing, the beginning and the foundation I've already made. Did you get your own baskets, or you practice at the school ones? You have to force your own baskets in the big hall, and due to the suggested games, you should do something also." (according to Paunić, 1981, 301)

Writing among them continues. From the same place on 3 March he sends the letter to Miodrag Stefanović again, in which, among other, says:

"Keep the games as you predicted, because there is no progress without games. You have a lot of players in use so you can combine a team: Travica, Mišeljić, Nikolić, Debelja, Vlahović, Šuput, etc. they could play really good with us, and I think they would not be weak. Did you played with Petrovgrad already? How the new players develop? Did you trained starts regularly, and how the old "aces" get along? ... because the players have contributed a lot to Matica this year, and not only in the sense of competition, but in all other areas, starting from the work in the Sokohall and so on." (Ibid)

$\mathrm{He}$ is probably talking about the game which is going to happen on 16 March 1941 in Belgrade between the teams of SS Zagreb II and SS Matica-Beograd.

Maržan continues with writing with his friends players. On the 3 of June 1941 he addresses the letter to R. Radovanović in Belgrade, in which, besides other things, says:

„I hear that some work could be done on summer playground in Kalemegdan. Gather yourself, brothers Stanko and Zvonko Neferović will try with Rafa to do something there, especially to play volleyball and basketball... so I send regards to all known basketballers, people from Matica and all others known and unknown, and especially You with a lot of memories and brotherly Goodbye! Majo." (Ibid)

\section{Basketball activities from 6th April until the end of 1941}

Historical development of basketball in the territory of former Yugoslavia until the end of 1941, and especially after the war, from 1945 forwards, is relatively good processed and highlighted, but the period during the WW II remained quite un-researched, so it would be useful and necessary to research and highlight that period too and rip it out of the oblivion.

Unfortunately, as Pavlović says:

"People here treat historical part of physical culture with a lot of negligence, better said historical sciences have been passive towards this area of human culture for quite some time, what brought a significant lack of methods and attention towards keeping and studying of those materials. From those reasons a very small number of primary historical documents were saved as same as other archive materials about physical culture during the War. That is also one of the reasons why in historiography literature, besides relatively rich memoir materials and popular affairs, we can rarely find scientific papers talking about the areas of physical culture.” (Pavlović, 1989, 3)

The same thing is with basketball, where also we can rarely find scientific papers about development of basketball in the time of WW II in the territory of former Yugoslavia.

Meaning and the role of sports, and with that also the meaning and the role of basketball, with us and in the world today is such that it cannot pass the attention of science, and by that out of the historical science, that is why bigger and bigger attention is on research of history of sports, and also the history of basketball during the War.

We could think that, in those war times, all troubles and hardness of war, in the territory of ex-Yugoslavia, people did not pay any attention to sports activities.

But that was not really the case. According to Pavlović:

"The happening, however, showed that the people, even in those circumstances, in spite of all difficulties and war troubles, found the strength and motives to, in small breaks, turn to themselves, their human culture identity. In that desire they did not 
forget sports contests nor other forms of physical culture. What's more, these activities were very often the only way of distraction, only chance to express and maintain cultural traditions and continuum of living at all." (Pavlović, 1989, 387)

About the basketball during the WW II, even do it was greatly played already, a long time people were silent and wrote very little about it. About that Nebojša Popović says:

"Aca and me met in 1942, when our basketball in occupied Belgrade "certainly" played. It was not clear to me too why everyone is silent about it... Belgrade was occupied, as the rest of the Serbia, but especially during the 1942 basketball was played. There were seven or eight teams, Aco played for Obilić, together with Milorad Sokolović, Ratko Kašanin, who later did his $\mathrm{PhD}$ in international law and also was the president of Basketball Federation of Serbia." (according to Stojković, 2000, 17)

In the time of the occupation of Belgrade basketball was played with almost the same intensity as before the War. It was played by not only the before-war players, but also all other athletes and school youth.

Basketball, as Stanislav Paunić says:

"in those so controversial and paradox circumstances of this sub-period still finds the way and possibilities not only to keep it self, but also to rise up comparing to the period before (Maržans 170 from all Yugoslavia in 1940 vs. 300 players and 23 clubs - just from Serbia, for example), and somewhere (Prizren, for example) to appear for the first time! For this, probably even in European measures unique presenting of it, is especially indicative the case of mentioned "appropriate sample", Belgrade, better said Serbia.” (Paunić, 2007, 187)

As the work of Sokol was forbidden by the occupant authority, the athletes who used to practice in Sokol societies transfer to other sports clubs. In clubs, among other things, forms basketball sections. One of the first ones is SK Jugoslavija (later SK 1913) that formed basketball section for man and woman which had a significant influence on basketball development in Belgrade. There were few sport clubs back then: SK Jugoslavija, BASK, BSK, BTK, Obilić, BOB, SASK, club of Vladan Mitić famous Belgrade trader, and others, which cherished basketball in new-formed basketball sections (clubs). Besides playing in clubs, they have played matches between themselves, organized the Championship of Belgrade in basketball (1941, 1942, and 1943) and worked on the popularization of basketball with Belgrade youth.

\section{PICTURE 3}

The game between two women teams (SK 1913 and BOB) during the occupation of Belgrade on Tašmajdan courts.

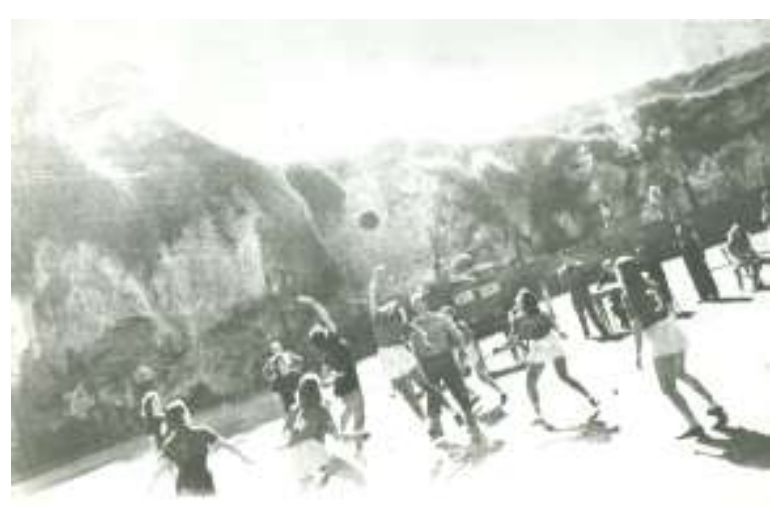

All above mentioned clubs had remarkable players, so the games between them were always interesting and amusing. They played most of all on Tašmajdan playground (playground of BTK) and in Kalemegdan (playground of $\mathrm{BOB}$ ).

About sports in Belgrade during those war days, journal "Kolo" states:

„First consequences of big changes in our sport appeared right after the War. It is noticed that the development of certain sports fields, which used to develop silently, without involvement of wider masses and no support, but thanks to a great sacrifice of certain individuals". (Anon, 1942, ?)

Mirko (Bata) Aksentijević ${ }^{1}$, participant of those happening, says about that:

„I have to say that there was a certain set of circumstances... we sort of... those players

1 Gave the interview to Stanislav Paunić on 7 April 1980, recorded on tape 
who have played in Matica... we were in SK 13 .... that was a pre-war Yugoslavia.. after Yugoslavia failed... the name of the club failed, so... they did not want to go back to the old name... but the number 13 as the number of the founding year of the club... that was the name they took and we were in SK $13 \ldots$ and we founded one male, female club... better said it was more than for just one team... there were around twenty young boys and girls who played basketball... there were... other clubs too... some BASK, than BTK, Obilić, Mitić... Vladan Mitić. Famous Belgrade trader... his son played basketball... he had his own team too... etc." (according to Paunić, 2007, 174-175)

President of the SK 1913 was Joca Ružić, coaches: Nebojša Popović, Mirko Aksentijević and Zvonimir Neferović, and beside them in the club were also Miodrag Stefanović, Aleksandar Petrović, Ivan Dimić and Vasa Stojković.

Soon after that is formed the section for basketball. The management of the section was elected. Miodrag Stefanović was the secretary, Zvonimir Neferović the technical officer, Ljubiša Galović ${ }^{2}$ the economist, board members of the club, Mirko Aksentijević and Veljko Ronac.

About those happenings leaves the inscription for the "Novo vreme" from 12 December 1941.

"As a first club in Belgrade it started to raise this sport SK 1913 which at the same time raises all sports. Starting to notice the value of basketball the management of SK 1913 decided to form and to cherish this game which is accepted by the youth so fast. On the founding meeting ... for the secretary Stefanović Miodrag, for technical officer Neferović Zvonko, for economist Ljub. Galović, board members are M. Aksentijević, V. Ronac". (Anon, 1941, ?)

That sports club (S.K. 1913) had a significant influence on the basketball development, not only in Belgrade, but in whole Serbia.

"This club not just in Belgrade, but in whole Serbia, started the actions for

2 Athlete, Serbian record holder in middle and long distance spreading the basketball. When the S. K. 1913 founded its basketball section, he leaned on whit all his strengths to work on the more and more interest of the athletes for this sport. Hard work of the board of the basketball section did not leave without" (Anon, 1942, ?)

About basketball section of the SK 1913 in the „Novo vreme“, from 25 March 1942 was published the text with the following:

"Before the War the basketball in our territory was in "dippers". Today, when we need to entirely reorganize our sports, we need to take care about this type of sport too. To a few young and workable people, which stood up to launch this sport among our athletes, should be helped. S.K. 1913, with founding basketball section, accepted friendly these people and helped them in their wanting to popularize more this sport among athletes and its fans. Ever since the last championship of Belgrade in basketball (1941 a.t.a), which was successful in every aspect, these young people worked on organization of the today's most beautiful sport. The whole set of players was made that way, which is preparing itself to as soon as possible stands before the Belgrade audience and shows it the beauty of this game: speed, strength, fire, endurance, agility. Every roughness, bad intentions and hate is excluded." (Anon, 1942, ?)

Nebojša Popović says:

"I played for the S.K. 1913, the inheriting club of the famous SK Jugoslavija. In those War years, the name Yugoslavia, even in sports, was forbidden to mention, so the compromise solution was found. For us the 1913 was historically significant, because of the Second Balkan War. Vasa Stojković, also our college, future editor of the 'Večernje novosti' journal, played for BSK, later BTK - it's a Belgrade tennis club, were Bora Stanković also played, today's leading man in basketball, general secretary of FIBA..." (according to Stojković, 2005, 2122)

In the S.K. 1913 basketball team besides Serbs played several Croats refugees. Popović says: 
"Those were the Yugoslav people. They escaped from the Independent Country of Croatia, and found their rescue in Belgrade. I remember Zvonko Neferović from Zagreb, Veljko Ronac from Šibenik, Vlade Mađeruh from Karlovac.” (Ibid, 23)

\section{PICTURE 4}

\section{Lined teams of SK 1913 (black) and Irbjeglice} (white) before the begging of game on Tašmajdan

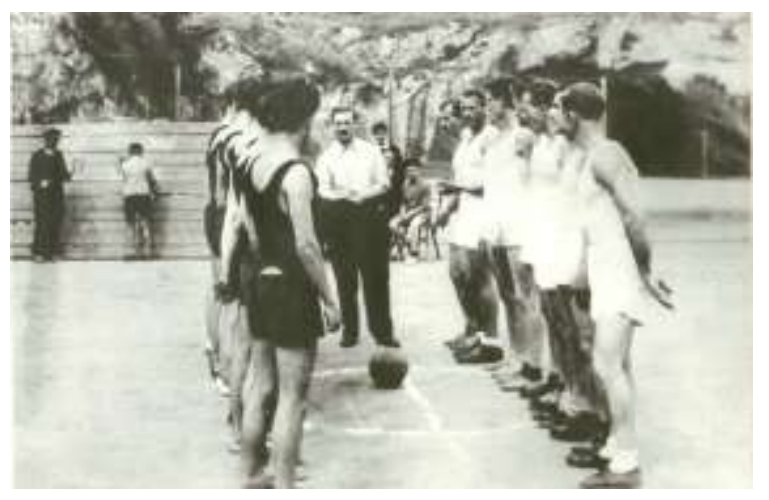

Aleksandar Petrović ${ }^{3}$, also the actor of those happenings is saying:

"During the occupation we continued in the S.K. 1913... former Jugoslavija... and... the trainings there were pretty serious... there gathered everyone that used to play in Soko or in the House of the King Aleksandar... one of them was Nebojša Popović... than Mija Stefanović... than Vasa Stojković, Bata Aksentijević, Nebojša Dimić from the Man's Third... played very good... those were quite strong teams... there were also a female teams... and we played among us... at the side court... and that was maybe... maybe for the young to gather... and the coach was Nebojša Popović, Bata Aksentijević and... Neferović... the president was Joca Ružić... and that he loved basketball very much... and on the other hand helped a lot... some very beautiful games were played... I know those were our nice days... in those hard times this was a sort of... refreshment." (according to Paunić, 2007, 177)

Svetislav Vulović ${ }^{4}$ says that he renewed

\footnotetext{
${ }^{3}$ Gave the interview to S. Paunić 18 June 1979, record-
} ed on tape basketball in Belgrade during the occupation. How it happened he says:

"I renewed basketball... during the occupation... there was the question of all young to go to the mine in Bor... then they came to me and said... if we would do something... that would have nothing to do with Germans, and they would not have any use from it... and they would like to play some sports... they could be saved from the mine... and with the personal lust I accepted that job... then it was played in the Belgrade tennis club... no tennis was played during the occupation... and I accepted to be their new pioneer... if you can call it that way... and from that generation are today's leaders and managers... Bora Stanković, Nebojša Popović, Šaper, Munćan... than Vasa Stojković, Mija Stefanović... and a lot of others... which continued... than it was played... sort of championships but the clubs were BTK, Jugoslavija, BSK, BASK... and it was played like that... for maybe two seasons." (according to Paunić, 2007, 177)

On other place he says that the idea came from Bora Jovanović:

"In the time of occupation no sports were played seriously except football. One day in the 1942 Bora Jovanović, future professor on DIF, came to me and says: Doctor Bato, I have a suggestion. It's a little bit dangerous. So the Germans would not force young people to go to the mines, or to die somewhere in the woods, there is a hope that they would be protected if they play some sport. But we will have to risk. You need to be the president of the basketball federation, and me, of the volleyball federation. And we set the basketball and volleyball playgrounds on my tennis courts, and form of the teams: SK 1913, BSK, BASK, Obilic, Mitic and BTK. There played a hundreds of young, and so were saved themselves from the mines." (according to Stojković, 2005, 21) About when he saw the baskets for the first time, when he started to play basketball, which

${ }^{4}$ Gave the interview to S. Paunić 5 June 1979, recorded on tape 
encouraged him, in what club, who played with him and like, Nebojša Popović, in the interview given to Stanislav Paunić in the 1979, among other things, says:

"...I graduated in the $1940 \ldots$ I met basketball in ' $42 \ldots$ following the circumstances... in that time of occupation.... In my street, not far from me, lived Ivan Dimić... in the football club Jugoslavija which was called SK 13 back than... was a goal keeper... sometimes I went with him to trainings... thanks to Nevenka Šešlija I went to that basketball... when I came there... after woman was a man training... one player was missing... there were nine of them... called me... and I liked it a little bit... and the same Zvonko Neferović who was living in Belgrade during the War in... in exile... because he, as an exponed Soko member and Yugoslavoriented Croat escaped the terror of ustaše in Belgrade, and there he, with few of his friends with the same orientation as Vlado Mađeruh... Veljko Ronac... he was also there working around basketball... leaded the SK 13 back then... was a coach and a player... and after that practice he said to me... why wouldn't you play... it was a little bit flattering to me... and I promised him I will come... 42.. 43 was already stopped... one decent basketball was played... but it had it's viewers than... in Belgrade was 6-7 clubs... back then... there was that SK 13, BSK, BASK, BTK, there was BOB, Mitić... SASK... there, seven I remembered now... Obilić was... there was one league." (according to Paunić, 2007, 176)

Nevenka Šešlija ${ }^{5}$ also remember those days: "Then came the War... which disturbed all of us... but still we had a pleasure to gather in some club again... to do some sports... and so prolonged that basketball "doing"... there was a lot of refugees who knew a lot about basketball... as Zvonko Neferović... and it is shore that we had a bit better basketball than the one from the beginning, so later... all of us... transferred to the clubs in new Yugoslavia... founded the

\footnotetext{
${ }^{5}$ Gave the interview to S. Paunić on 15 April 1980, recorded on tape
}

basketball section of Red Star... Mirjana Janačković was in the Zagreb team... and later came to our refugee team... in $913 \ldots$ she was a refugee." (according to Paunić, 2007, 176)

\section{Belgrade}

Refugees (athletes) which, during those war days, came from all parts of the former Yugoslavia, gave a significant contribution to a development of sports, and not only in Belgrade, but in whole Serbia in that War period. According to Miloš Hamović:

"In a mass of refugees who came to Serbia from all parts of the occupied Yugoslavia was a significant number of athletes. They were provided to do any sports they played back home, but with the condition that they are successful sportsmen so the domain clubs would pay attention to them. Same as that, the chance to continue their activities in this new environment got also the coaches and referees ${ }^{6}$ of all different kind of sports, and sport-workers too." (Hamović, 1994, 224)

Athletes (refugees) who were welcome as an improvement to all sports, and most of all Belgrade clubs: football (Stanković, Đajić, Manola, Radojčić, etc.), athlete (dr Narančić, dr Manojlović, Stepišnik, Lukač, Kovačević, Ćurčić, etc.), basketball, volleyball and other, according to the mentioned author, Belgrade press gave them a lot of space:

"...besides that they did not save compliments about their qualities. In numerous articles their contribution to progress of sports in Serbia was pointed out with the possibilities for their involvement to be of great success in the international competition. Besides football it was pointed out that the athletics could gain a significant improvement, because among refugees were pre-war state champions and record holders, as for example, Rade Ćuričić from Zagreb." (Ibid, 226)

${ }^{6}$ In May of 1942 in Belgrade, besides the referee sports organization, a fond for helping the poor football refugee referees and the Serbians who were in hostile was founded (Obnova, 8 May 1942) 
Refugees (athletes) in many sports (basketball, football, volleyball, athletics) had their teams, which have often had a competition with the representation of Belgrade and participated in many other competitions (tournaments) in Belgrade.

A significant influence on basketball development, among other factors, had refugees (basketball players) from different parts of Yugoslavia, especially from Croatia (Zvonimir Neferović, Veljko Ronac, Marjan Maržan, Vlado Mađeruh, Mileta Tešin, Nevenka Šešlija, Mirjana Janačković and others). Not only they played basketball in different Belgrade clubs, but they participated in the First basketball championship in Belgrade during the WW II with their team „Izbjeglice“.

First basketball championship of Belgrade, in the time of War, was held on 27 and 28 September 1941.

Before the competition in the journal „Novo vreme" from 24 September 1941, besides the competition propositions was also addressed the call to basketball referees from other parts of Yugoslavia who are going to be in Belgrade during those days, to register to the supreme referee Zvonimir Neferović.

"Applied teams can compete only if they are uniformly dressed. Every team is obligated to have their own ball. Besides the invited referees we kindly ask all other basketball referees from other parts of the former Yugoslavia, and who are now in Belgrade, to register to the supreme referee, Mr. Neferović at latest one hour before the start of the competition." (Anon, 1941, ?)

„Novo vreme“ journal, from 26 September 1941 informs the readers, especially fans of basketball, that on Saturday and Sunday of that month, for the first time during the War, will be held the competition in basketball for the championship of Belgrade. They specially mention that one team of refugees-basketball players will compete and that the team „Matica" under the lead of coach Marjan Maržan is very well prepared, so they could show the viewers that they have deserved to be the unofficial champs of the Serbia for the last year.

"Fans of this interesting game will have the chance for the first time after the War to see the competition in basketball. We especially mention that one team of refugees who are now in Belgrade and do some serious training will also take part in the competition. Players of the "Matica" team who are very well prepared by their coach Mr. Marjan Maržan will play again to show and convince the audience that they really deserved to be called the unofficial champs of Serbia. Besides them two female teams will also take part and they will show that basketball is not only for man, but for the women too." (Nenadović, 1941, ?)

Championship is organized by the basketball section of the SK ,Jugoslavija“ (later SK 1913). Five teams took part in the competition: Matica, Omladinac, Izbeglice, SASK (High school amateur sports club) and Jugoslavija. Supreme referee was Zvonimir Neferović. The best team was Matica and they have deserved to win the first place.

In „Novo vreme“ from 29 September 1941 about that competition is written the following:

"On Saturday and Sunday was held the championship of Belgrade in basketball. The best and most shore team was "Matica", who deserved to win the first place. The basketball championship was organized by the young section of the SK "Jugoslavija". Fans of this beautiful and interesting game came in large number and cheered for their teams. These teams participated: Matica, Izbeglice, Omladinac, SASK and Jugoslavija." (Nenadović, 1941, ?)

In revised documents we did not find, for now, more details about that championship. It stays unknown if the two, and which, female teams took part in the competition, as the "Novo vreme“ announced in the number from 26 September 1941. It also stays unknown who did, besides Zvonimir Neferović, refereed the games, how many of them were played, who played with whom, the scores, as also other details regarding the championship.

After the end journal „Novo vreme“ from 4 October 1941 recorded one interesting detail about how the players of SK Matica and SK Jugoslavija agreed to come to the playground of SK Jugoslavija so they could sign to the newly formed basketball section of SK Jugo- 
slavija. The players came as agreed. But they couldn't sign in. The reason why we quote in the following text:

"After the state basketball championship in Belgrade, the players of SK "Matica" and the players of the SK "Jugoslavija" came, as agreed, to the playground to sign for this newly formed section of SK "Jugoslavija". But, on the greatest surprise of all future players of SK "Jugoslavija" they were told: "Gentleman, you cannot sign with us." The reason - the ball is missing." (Anon, 1941, ?)

In the „Novo vreme“ from 27 October 1941 a text titled „On Sunday resolves the question of trophy owner for basketball and volleyball" was published, and in the same journal, from 29 September 1941 a text under the title „Matica won the Belgrade basketball championship".

On those bases we can state that besides the Belgrade championship, some other basketball competition for some other trophy was going on.

On that Sunday, in the month of October 1941, the match between female teams of BOB and SK 1913 was played. The BOB won with the result 12-9 (5-6). The referee was Mileta Tešin.

For BOB team played: Vojvodić, Radovanović, Janačković I, Janačković II, Komnenović, Petrović and Mladenović, and for the SK 1913: Aksentijević, Uzelac I, Uzelac II, Uzelac III, Gavrilović and Šešlija. For SK 1913 scored: Gavrilović (6) and Šešlija (3), and for the BOB: both Radanović and Petrović 4, Janačković II (2) and Komnenović (2).

In the „Novo vreme“ writes:

"Referee M. Tešin, good. Defeat again. Ladies of the SK 1913 two defeats in two weeks." (Anon, 1941, ?)

What means that the female team of SK 1913 played one game the week before which they have also lost, but it stays unknown with who they played, the result, roosters as other details too.

Maybe it's those two teams that „Novo vreme" announced in the number from 26

November 1941.

"Besides these ones, two female teams will also take part and they will show that basketball is not only for man, but for the girls too." (Nenadović, 1941, ?)

\section{Forming of the Serbian basketball feder- ation}

„Novo vreme“ on the 31 August 1941 published the news that after the First Belgrade championship in volleyball, which will be held in the first week of the same year, will start with the forming of the Federation for basketball and volleyball. It is not mentioned if it is the Federation of Belgrade or Serbia.

\section{PICTURE 5}

Svetislav Vulović

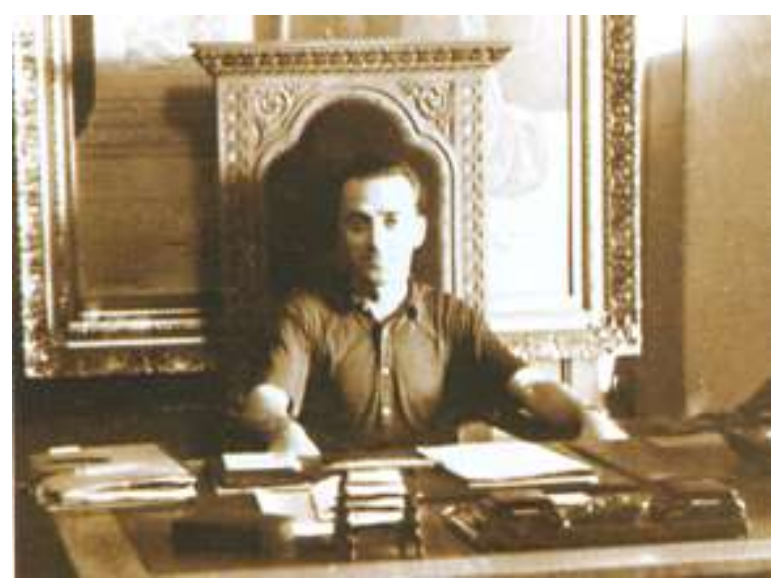

"During the next week the first Belgrade championship in volleyball will be held among clubs and societies that cherish this game. After this championship will be stared the founding of Federation for volleyball and basketball." (Novo vreme, 30. august 1941)

In the first part of September 1941 the Serbian basketball and volleyball federation was formed. Svetislav Vulović was elected for the first president. Technical officer was Bora Jovanović.

Besides spreading the basketball, not only in Belgrade, but in whole Serbia, Federation also organized competitions, formed new clubs and sections, worked on their own rules, basketball rules, and on the emprovement and organization of the referee staff.

Besides Belgrade basketball was played in other places (Novi Sad, Petrovgrad, Subotica, Šabac, Kragujevac, Niš, Prizren, Split, Zadar, 
Dubrovnik, Sibenik, Kotor) in the territory of former Yugoslavia, with different intensity.

In some places, besides playing basketball, occupation army formed clubs, introduced it to schools, propagated and spread it among youth and other population, first of all because of the political and ideological influence, and all in cause of the denationalization of occupied population, for example in Novi Sad, Petrovgrad and Subotica it was done by the Hungarians, and in Prizren, Split, Zadar and Kotor by the Italian occupant authority.

\section{Novi Sad}

Pavlović writes that:

"During the occupation there was no organized basketball section. The exception is the high school competition in Novi Sad as a part of the championship of the socalled South Hungary." (Pavlović, 1977, 52) Janik Ferenc, in his conversation with Stanislav Paunić on the 30 August 1978 in Novi Sad, says:

"School for teachers Novi Sad... in the time of Hungarians... we learned basketball... Steva Putnik came from Zrenjanin to Novi Sad, to work on basketball here in Novi Sad." (Paunić, 2007, 186 i 251)

More detailed description of basketball activities in Novi Sad during the War gave A. Miklović in his paper „Evolution of basketball in Novi Sad". He writes that after the occupation of Novi Sad by the Hungarian army, and after the arrival of teachers and all sort of other officers from Budapest, Segedin and other places of Hungary, basketball started in schools. The biggest credit for the introduction of basketball in schools goes to the teachers of physical education who started with the founding of basketball sections in schools they worked in.

"In very short time in high schools in Novi Sad the youth practiced basketball "alphabet" with the great excitement. In the same year the UAC (ujvidéki atletikai club) club from Novi Sad contracts its first basketball coach Lehel Tibor from Segedin, who will work as a Boarder Officer and a coach of teams in Novi Sad untill the end of the War. By the conversation with the former player of this club (Bozo Oskar), we find out that Lehel was a great expert and a pedagogist, and that it's his contribution that basketball in Novi Sad in a very short time gain a lot of simpatisers and the level of teams from Segedin and other towns of South Hungary. Pupils were trained by their teachers of physical culture (gymnastics). In the Teacher's and technical high school the teacher was Lucak (Luczák), and ih Hungary Gymnasium was Kalmancai Zoltan, and in Traiding accademy and in Gymnasium with Serbian language Moldovani Ištvan (Moldovanyi Istvan). They trained in halls in their schools and in that time Partizan hall I ( then Levente othón). The playround was marked with chalk or calx and a stands for hight jump were used to attach the hoop." (Miklović, 1972, 11-12)

In the school year 1941/42 the interschool championship of the city was held. Six teams competed: Teacher's school, Hungary and Serbian Gymnasium, Trading academy, Agriculture and technical high school. The team of the Technical high school (IKY) won the first place, by beating all other teams. At the end they played the match with the representation of Novi Sad high schools, which they, also, defeated with the score 32-24. In the IKY team played: Janković, Taboroši, Segedinčev, Banko, Dević, Kiš and Gerdov.

\section{Split}

Đuro Vujanić in the letter from 23 March 1979 addressed to Stanislav Paunić, writes:

"During the occupation people from Zadar transfer the basketball to Šibenik and Split. In Split basketball caches deep roots and thanks to the Carbonini and Stefanini brothers (after the War, these last two played for "Reyr" from Venice) it manages to surpass ban." (Paunić, 2007, 185)

Toni Petrić says:

"But we have to admit that the basketball in Split was "born" during the Italian occupation of Split in the WW II in the rope of fascist youth organizations." (Petrić, 2000a, ?)

In the time of Italian occupation (1941- 
1943) basketball plays in Split. The Italian soldiers and Italian youth from Split played it. The youth had two organizations „GIL“ (Gioventu Italiana di Littorio) and „GUF“ (Gruppo Universitario Fascista) in which was played basketball. They played some games from time to time. The Italians tried to gather in those organizations as many young people from Split as they could, most of all pupils from the elementary schools, so they could have the bigger ideological influence they possibly can, but they did not have such a great success in that.

"After taking over the Italians were in a hurry to start with the process of denationalization of our people, better said quick Italianization and fascization of all people attached to Italians. The main ways of terrorization were the general measures of Italianization with the emphases on fascization of young, better said signing in to GIL (Gioventu Italiana di Littorio). They went to the first and second grades of highschool, today's fifth and sixth grade of elementary school. The children and the parents were enteminated, parents were thretened to lose their jobs if their children don't sign in that organization. The emphasis was on the younger generations, because they have expirienced a total failure with the pupils of the higher grades." (Petrić, 2000b, ?)

Duško Marović writes that after arrival to Split occupation solders:

"Occupied all sports societies, gave them new, Italian names, so they have also occupied the summer playground of Soko society Split from which they took our first baskets and transferred them to the courts of the former Academic Tennis Club (ATK) around Firul were they played the first basketball game.“ (Marović, 1982,329) During the 1941 „GIL“ and „GUF“ played several games in Split and Zadar.

On the $26^{\text {th }}$ July of the same year was played probably the first game on Firula between GIL and GUF teams. The GUF team won 49-25. The referee was the leftenet of the Italian Army Mazzini. In the GIL team played: Dante Stipizza, Bruno Candutti, Vincezno Carbonini, Bartolomeo Veloce, Giovanni
Paolicevich, Eugenio Romanich, Vittorio Volich and Patrizio Lunazzi, and in the GUF team: Romano Foretich, Corrado Minussi, Guerino Senizza, Luciano Cuccoch, Matteo Romich, Severio Fiorentini one and Severio Fiorentini two.

Italian daily journal „San Marco“ that came out in Split, in number from 28 July 1941 wrote about that game.

\section{PICTURE 6}

Picture from the newspaper about basketball game played in Split in November 1941

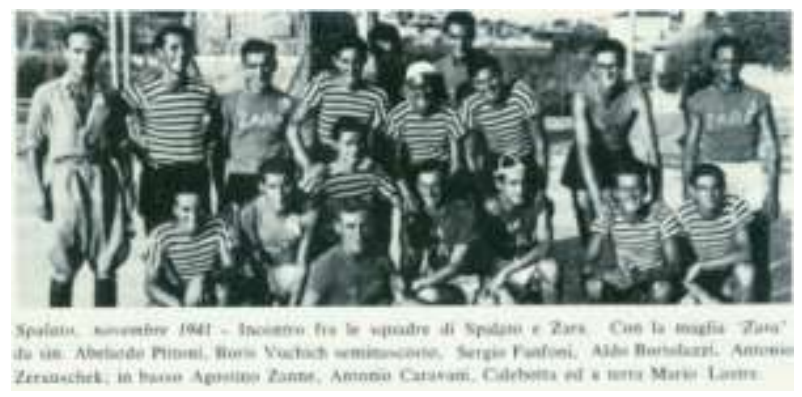

By the end of November 1941 one more game between the „GIL-Spalato“ and „GILZara" was played, Marović writes that the Italian journal „II Popolo di Spalato" in number from 2 December of the current year brought the annunciation about the played game. For Zadar played: Abelardo Pittoni, Boris Vuchich, Sergio Fantoni, Aldo Bortolazzi, Antonio Zerauschek, Agostino Zanne, Antonio Caravani, Calebotta and Mario Lastre.

According to Petrić women also played basketball and participated in competitions organized in Split and other places. The students of Split high schools also played basketball and games between themselves. During the 1941, as Petrić writes, was played:

"...more games in Split and outside of the city in male and female competition and two games between the students of the Classic and Men's real Gymnasium." (Petrić, 2000a, ?)

\section{Dubrovnik}

About playing basketball in Dubrovnik in the time of the WW II we only found noted the memory of Vlaho Kojaković. 
He was a student of the School for physical education with his people from Dubrovnik: Vinko Cvjetković, Luka Ciganović, Pero Matan and Marija Kolarić, and people from Split: Natko Lahman and Uroš Tominić. There he met basketball. After bombing of Belgrade on 6 April 1941 he returns to his Dubrovnik. On the same year he started to work as a professor of physical education in Dubrovnik gymnasium.

Kojaković remembers:

"I started to work in Gymnasium, and that basketball was always on my mind. I also knew that I will be ridiculous to a lot of people if I start to teach boys and girls how to play basketball in a city of swimming and water-polo. But, I started, no matter what happens. And right at the beginning I started with a very pleasant surprise: in Dubrovnik existed one wooden basket made by a professor Ivo Kresić! I started to teach a group of young man to basketball "alphabet" on that basket. We played with that football ball, the basket was made from wood, hoop improvised... after two-three months I was surprised because around ten boys always wanted to play basketball. But in Dubrovnik it started to play more organized after the end of the WW II in 1945. The wooden basket of Ivo Kresić was still alive." (Bibić, 2003, 12)

\section{[ibenik}

About basketball in Šibenik only one data was available to us, left by Đuro Vujanić in a letter from 23 March 1979, addressed to Stanislav Paunić, in which, among other things, he writes:

"During the occupation people from Zadar transfer the basketball to Šibenik and Split." (Paunić, 2007, 185)

It is quite believable that basketball occasionally played among youth.

\section{Kotor}

In the time of War basketball starts in Kotor in 1941, right after the occupation of Boka Kotorska by the Italian army. The most credits for spreading of basketball goes to professor of Italian language, Italian Srđa Paronucija.
Close to Kotor Italian government founded a sports camp, with all a lot of sports device and equipment and among them were also the baskets. Paronucija formed a basketball team from Italian solders with whom he practiced. And not only had he learned the Italian solders how to play basketball, but he did the same thing with Kotor youth. They played matches occasionally. Several matches were played but did not get recorded.

\section{REFERENCE:}

Anon. (1941). Propositions for championship of Belgrade. [Propozicije za prvenstvo Beograda. In Serbian.]. Novo vreme, September 24, 1941.

Anon. (1941). ?., Novo vreme, August 30, 1941

Anon. (1941). ?. October 4, 1941.

Anon. (1941). SK 1913 is the most respectable club in this type of sports. [S.K. 1913 je najagilniji klub u novoj grani sporta. In Serbian.]. Novo vreme, Friday, December 12, 1941.

Anon. (1941). On Sunday resolves the question of basketball and volleyball trophy owner. [U nedelju se rešava pitanje osvajača pehara u košarci i odbojci. In Serbian.]. Novo vreme, October 27, 1941.

Anon. (1942). Basketball - the game of the future. [Košarka - igra budućnosti.]. Novo vreme, Wednesday, March 15, 1942.

Anon. (1942). Basketball - sport of the school youth. [Košarka - sport školske omladine. In Serbian.]. Kolo, April 11, 1942.

Anon. (1942). Around 1.500 spectators on the basketball game. [Oko 1.500 gledalaca na utakmici košarke. In Serbian.]. Kolo, April 18, 1942.

Bibić, M. (2003). Vlaho Kojakovic from Dubrovnik, a 91-year old pioneer of the Dalmatian basketball. [Dubrovčanin Vlaho Kojaković, 91-godišnji pionir dalmatinske košarke Slobodna Dalmacija. In Croat.]. October 13, 2003. Available at: www.arhivaslobodnadalmacija. hr/200312013/Presing12.asp.

Hamović, M. (1994). Exile in Bosnia and Herzegovina from 1941 to 1945. [Izbjeglištvo u Bosni i Hercegovini 1941-1945. In Serbian]. Beograd: „Filip Višnjić“ - posebna izdanja. 
Maržan, M. (1941). Basketballs game in Belgrade. [Utakmica košarka u Beogradu. In Serbian.]. Jugoslovenski sport i vazduhoplovstvo, 2, p. 38.

Maržna, M. (1941). Basketball games in Belgrade. [Utakmice u košarci u Beogradu. In Serbian.]. Sokolski glasnik, 4, p. 6.

Marović, D. (1982). The beginnings of basketball in Split. [Počeci košarke u Splitu. In Croat.]. Povijest sporta, 53(13), pp. 323-332.

Miklović, A. (1972). The basketball evolution in Novi Sad. [Evolucija košarke u Novom Sadu. In Serbo-Croatian.]. Final paper. Sarajevo: Visoka škola tjelesne kulture.

Nenadović, Lj.D. (1941). On Saturday and Sunday will be held the championship of Belgrade in basketball. [U subotu i nedelju oržaće se prvenstvo Beograda u košarci. In Serbian.]. Novo vreme, September 26, 1941.

Nenadović, Lj.D. (1941). „Matica“ won the Belgrade basketball championship. [,Matica“ je osvojila prvenstvo Beograda u košarci. In Serbian.]. Novo vreme, September 29, 1941.

Paunić, S. (1982). Genesis and development of basketball in Yugoslavia. [Geneza i razvoj košarke u Jugoslaviji. In Serbian.]. (Published doctoral dissertation, University Belgrade). Beograd: Fakultet fizičke kulture.

Paunić, S. (2007). Genesis and development of basketball in Yugoslavia. [Geneza i razvoj košarke u Jugoslaviji. In Serbian. ]. Kovin: Ženski košarkaški klub.
Pavlović, M.L. (1977). History and development of the game. Theory of basketball I part. IIstorija i razvoj igre. Teorija košarke I deo. In Serbian.]. Novi Sad: Zavod za fizičku kulturu Vojvodine.

Pavlović, D.P. (1989). Physical culture in NOB in the territory of todays SR BIH in the period from July 27, 1941 until May 9, 1945. [Fizička kultura u NOB na teritoriji današnje SR BiH u vremenu od 27. jula 1941. do 9. maja 1945. godine. In Serbian.]. (Unpublished doctoral dissertation University Novi Sad). Novi Sad: Fakultet fizičke kulture.

Petrić, T. (2000a). Why Split is the ,sportiest city in the world“. There are no sports without Split. [Zašto je Split ,najsportskiji grad na svitu“. Nima sporta do Splita. In Croat.]. Slobodna Dalmacija, February 21, 2000. Available at: www.arhivaslobodna dalmacija.hr/2000221/prilozisp2-htm.

Petrić, T. (2000b). Unbowed athletes. Sports in Split since 1941 to 1945 . [Nepokoreni sportaši. Sport u Splitu od 1941 do 1945. In Serbian.]. Slobodna Dalmacija, March 20, 2000. Available at: www.arhivaslobodna dalmacija.hr/2000320/prilozisp2-htm.

Stojković, S. (2005). Nebojša Popović always first. [Nebojša Popović uvek prvi. In Serbian.]. Beograd: Košarkaški savez Srbije i Crne Gore, Košarkaška fondacija.

Received: November, $10^{\text {th }} 2010$ Accepted: December, $8^{\text {th }} 2010$

Correspodence to: Slobodan Simović, PhD Faculty of Phisical Education and Sports Bulevar Vojvode Petra Bojovića 1A 78000 Banja Luka

Bosnia \& Herzegovina Phone: +38766828066

Fax: +38751312280

E-mail:ssimovic@hotmail.com 


\title{
KO[ARKA NA PROSTORIMA BIVIE JUGOSLAVIJE TOKOM 1941. GODINE
}

\author{
Simović Slobodan ${ }^{1}$, Pavlović Petar ${ }^{1}$, Pantelić Kristina ${ }^{1}$ i Grgić Zrinko $^{2}$ \\ ${ }^{1}$ Fakultet fizičkog vaspitanja i sporta, Banja Luka, Bosna i Hercegovina \\ ${ }^{2}$ Hrvatski športski muzej, Zagreb, Hrvatska
}

Razvoj košarke na prostorima o kojima je riječ, za vrijeme II svjetskog rata, ostao je do danas nedovoljno istražen, pa nam je predmet i cilj ovoga rada da taj period razvoja košarke istražimo, proanaliziramo, rasvjetlimo njegov razvoj i otrgnemo od zaborava.

Prilikom pisanja rada korišćena je uobičajena istorijska metoda (pronalaženje primarnih istorijskih izvora, njihova kritika, kao i pronalaženje $i$ proučavanje sekundarnih istorijskih izvora). Pregledani su i konsultovani brojni izvori koji su nastali u to vrijeme (časopisi, novine, listovi, zapisnici, izvještaji, prepiske $\mathrm{i}$ dr.) u: arhivima, biblitekama, instistutima, privatnim arhivima i muzejima sporta bivše Jugoslavije kao i izvori koji su nastajali poslije toga perioda.

U organizaciji Načelništva Saveza Sokola Kraljevine Jugoslavije je u Beogradu, od 2. do 6. januara 1941. godine u Domu sokolskog društva Beograd - Matica, u Deligradskoj br. 27 održan savezni tečaj za košarku. Voditelj tečaja je bio Marjan Maržan i svi primljeni kandidati morali su se prijaviti, 2. januara do 14.30 časova, Maržanu.

U Beogradu su 19. januara 1941. godine, u dvorani Sokolskog doma Soko Beograd I, odigrane tri košarkaške utakmice. Takmičilo se šest ekipa: tri ekipe Sokolskog društva Matica Beograd (članovi, naraštajci i naraštajke), dvije ekipe studenata (muškarci i žene Škole telesnog vaspitanja iz Beograda) i ekipa Sokolskog društva Soko I iz Beograda. Prva utakmica je odigrana između naraštajki sokolskog društva Matica - Beograd i studentica Škole telesnog vaspitanja. Pobijedile su studentice rezultatom 7-6 (6-6). Drugu utakmicu su odigrali članovi Matice i studenti ŠTV, uz prisustvo velikog broja gledalaca. Utakmica se završila pobjedom Matice rezultatom 23-22. U trećoj, posljednoj utakmici, sastali su se naraštajci
Matice sa ekipom Sokola I. Sokoli su zasluženo pobijedili rezultatom 14-8 (12-6).

Može se pomisliti da s početkom ratnih dešavanja i sa svim teškoćama i ratnim nedaćama, na prostorima tadašnje Jugoslavije, ljudi nisu uopšte posvećivali pažnju sportskim aktivnostima. O košarci za vrijeme II svjetkog rata, iako se uveliko igrala, dugo vremena se ćutalo i vrlo malo pisalo. No za vrijeme okupacije u Beogradu se igrala košarka gotovo sa istim intenzitetom kao i prije rata. Igrali su je ne samo predratni košarkaši, već i ostali sportisti i školska omladina.

Kako je rad Sokola bio zabranjen, od strane okupatorske vlasti, to sportisti koji su do tada vježbali u sokolskim društvima prelaze u druge sportske klubove, gdje nastavljaju vježbanje. U klubovima se, pored ostalih, formiraju i košarkaške sekcije. Među prvima je u SK Jugoslavija (kasnije SK 1913) formirana košarkaška sekcija i za muškarce i za žene koja je imala značajan uticaj na razvoj košarke u Beogradu. Postojalo je u to vrijeme više sportskih klubova: SK Jugoslavija, BASK, BSK, BTK, Obilić, BOB, SASK (Srenjoškolski amaterski sport klub), Klub Vladana Mitića, poznatog beogradskog trgovca i dr, u kojima se gajila košarka u novoformiranim košarkaškim sekcijama (ekipama). Pored igranja u klubovima oni su igrali i međusobne utakmice, organizovali prvenstvo Beograda u košarci (1941, 1942, 1943) i radili na popularizaciji košarke među beogradskom omladinom. Svi naprijed navedeni klubovi su imali odlične igrače, tako da su utakmice između njih bile uvijek interesantene i zanimljive. Najviše se igralo na terenima na Tašmajdanu (igralište BTK) i na Kalemgednau (igralište BOB-a).

$\mathrm{Na}$ razvoj košarke znatnog uticaja, pored ostalih faktora, imali su i izbjeglice (košarkaši) iz drugih dijelova Jugoslavije, naročito iz Hrvatske (Zvonimir Neferović, Veljko Ronac, 
Marjan Maržan, Vlado Mađeruh, Mileta Tešin, Nevenka Šešlija, Mirjana Janačković i drugi). $\mathrm{Ne}$ samo da su igrali košarku u raznim beogradskim klubovima, već su i na Prvom košarkaškom prvenstvu u Beogradu, za vrijeme Drugog svjetskog rata, nastupali sa svojom ekipom „Izbeglice“.

Prvo košarkaško prvenstvo Beograda, za vrijeme rata, održano je 27. i 28. septembra 1941. godine.

Prvenstvo je organizovala košarkaška sekcija SK „Jugoslavije“ (kasnije SK 1913). Na takmičenju je učestvovalo pet ekipa: Matica, Omladinac, Izbeglice, Sask (Srenjoškolski amaterski sport klub) i Jugoslavija.

U prvoj polovini septembra 1941. godine osnovan je Srpski savez košarke i odbojke. Za prvog predsjednika izabran je Svetislav Vulović. Tehnički referent je bio Borivoje Jovanović. Savez je pored rada na širenju košarke ne samo u Beogradu, već i cijeloj Srbiji, organizovao takmičenja, osnivao nove klubove i sekcije, radio i na izradi svojih pravila, pravila košarke i na poboljšanju i organizaciji sudijskog kadra.

Pored Beograda košarka se igrala i u drugim mjestima (Novi Sad, Petrovgrad, Subotica, Šabac, Kragujevac, Niš, Prizren, Split, Zadar, Dubrovnik, Šibenik, Kotor) na prostorima bivše Jugoslavije, sa različitim intenzitetom.
U školskoj 1941/42 godini održano je međuškolsko prvenstvo grada. Na takmičenju je učestvovalo šest ekipa: Učiteljske škole, Mađarske i Srpske gimnazije, Trgovačke akademije, Poljoprivredne i Srednje tehničke škole. Prvo mjesto je osvojila ekipa Srednje tehničke škole (IKY), pobjedivši sve ekipe. Na kraju su odigrali utakmicu sa reprezenatcijom novosadskih škola koju su, takođe, pobijedili rezultatom 32-24.

Za vrijeme italijanske okupacije (19411943) košarka se igrala u Splitu. Igrali su je Italijanski vojnici i Italijanski omladinci iz Splita. Omladinci su imali svoje dvije organizacije „GIL“ (Gioventu Italiana di Littorio) i „GUF“ (Gruppo Universitario Fascista) u kojima se igrala košarka. Tokom 1941. godine „GIL“ i „GUF“ su odigrali nekoliko utakmica u Splitu i Zadru.

U Dubrovniku je postojao jedan drveni koš kojega je napravio profesor Ivo Krešić! Na tom košu grupa mladića počela je da uči košarkašku abecedu tokom 1941. godine pod rukovodstvom profesora dubrovačke gimnazije Vlaha Kojakovića.

Košarka se za vrijeme rata počela igrati u Kotoru 1941. godine, odmah po okupaciji Boke Kotorske od strane Italijanske vojske. Najzaslužniji za širenje košarke je bio profesor italijanskog jezika, Italijan Srđa Paronucija..

Ključne riječi: košarka, takmičenja, Drugi svjetski rat. 